\title{
Web Appendix (B-F): The Labor Market Returns to Cognitive and Noncognitive Ability: Evidence from the Swedish Enlistment
}

\author{
Erik Lindqvist and Roine Vestman*
}

April 13, 2010

\begin{abstract}
This Web Appendix provides additional material to the paper "The Labor Market Returns to Cognitive and Noncognitive Ability" published in in American Economic Journal: Applied Economics.
\end{abstract}

\section{Appendix B: Sample selection}

This Appendix analyzes several issues related to sample selection. Table B1 gives the summary statistics for the additional variables used in Appendix B-F.

\section{$1.1 \quad$ Missing wages}

As already discussed in Section 2 in the paper, we do not observe wages for the entire sample. One reason is that employers do not report them to Statistics Sweden. If such workers are not systematically different from workers with observable wages in terms of the relationship between skills and wages, this will not bias our estimates. A more serious problem is that we do not observe wages for men who do not work. Though there is no minimum wage law in Sweden, the effective minimum wage is relatively high due to the strong influence of trade unions and the extensive welfare system. This implies that men with low productivity or a strong preference for leisure may be selected out of the labor market. Following Gronau (1974), suppose men select into the labor market in case the offered wage $\left(w_{i}\right)$ exceeds the reservation wage $\left(w_{i}^{r}\right)$, which is given by

${ }^{*}$ Lindqvist: Research Institute of Industrial Economics (IFN), Box 6501, SE-102 15 Stockkholm, Sweden (e-mail: erik.lindqvist@ifn.se). Vestman: Economics Department, New York University, 19 W. 4th Street,6FL, New York, NY 10012 (e-mail: roine.vestman@nyu.edu). 


$$
\log w_{i}^{r}=\beta_{c 2} c_{i}+\beta_{n 2} n_{i}+\mathbf{X}_{i} \gamma_{2}+\varepsilon_{i 2} .
$$

Hence, we observe wages if and only if

$$
\log w_{i}-\log w_{i}^{r}=\beta_{c}^{\prime} c_{i}+\beta_{n}^{\prime} n_{i}+\mathbf{X}_{i} \gamma^{\prime}+u_{i}>0
$$

where $\beta_{c}^{\prime} \equiv \beta_{c}-\beta_{c 2}, \beta_{n}^{\prime} \equiv \beta_{n}-\beta_{n 2}, \gamma^{\prime} \equiv \gamma-\gamma_{2}$ and $u_{i} \equiv \varepsilon_{i}-\varepsilon_{i 2}$. Let $I=1$ denote the case when $w_{i} \geq w_{i}^{r}$ and $I=0$ the case when $w_{i}<w_{i}^{r}$. A selection bias occurs in case $u_{i}$ is correlated with $\varepsilon_{i}$. We use four different methods to deal with this potential problem.

Our first approach is to test if our results are sensitive to whether imputed wages are included or not. The results reported in the text considered the case when wages in 2006 were imputed from observed wages in the 2001-2005 period. Here, we consider the case when we exclude all imputed wages and when an imputed wage is added also for some of the men whose wage is unobservable in the entire 2001-2006 period. We impute wages from the predicted values from a regression of monthly (full-time equivalent) wages on a fifth-order polynomial in annual income. The table below summarizes the different wage measures used in the paper.

\begin{tabular}{lll}
\hline \hline Measure & Method & $N$ \\
\hline W1 & Wages observed in 2006 & 12,570 \\
W2 & W1 + imputed from observed wages in 2001-2005 if W1 is missing & 14,038 \\
W3 & W2 + imputed from annual earnings if W2 missing & 14,703 \\
\hline \hline
\end{tabular}

Our second approach is median regression. The advantage of median regression over OLS is that the results are only affected by the position of the imputed wage with respect to the conditional median. ${ }^{1}$ Hence, the results from median regression are not sensitive to the exact value of imputed wages. If log wages are linear in $c$ and $n$, median regression identifies the same parameter as OLS. To assign men with missing wages an imputed wage on the right side of the conditional median, we calculate the predicted values from a median regression of the logarithm of annual earnings on $\left(c_{i}, n_{i}, \mathbf{X}_{i}\right)$. Let $w_{i}$ denote the wage from either of our three wage measures described in Section 2 and $K_{i}$ denote an in-

\footnotetext{
${ }^{1}$ Bloomfield and Steiger (1983) provide the mathematical details for this result. Other papers that have used median regression to control for selection bias are Neal and Johnson (1996), Neal (2004) and Olivetti and Petrongolo (2008).
} 
dicator variable equal to one in case actual earnings exceeds predicted earnings and equal to zero in case actual earnings falls short of predicted earnings. For each wage measue, we then create a new variable $y_{i}=w_{i}$ if $I_{i}=1, y_{i}=0$ if $I_{i}=0$ and $K_{i}=0$ and $y_{i}=10^{8}$ if $I_{i}=0$ and $K_{i}=1 .^{2}$ In other words, we assign men with missing wages and an annual earnings below the conditional median a wage below the conditional median, and men with missing wages but an annual earnings above the conditional median a wage above the conditional median.

Our third approach is to employ the two-step procedure proposed by Heckman $(1976,1979)$. As we do not have a valid instrument for selection into the labor market, we rely on the nonlinearity of the inverse Mill ratio to identify $\left(\beta_{c}, \beta_{n}, \gamma\right)$. Leung and $\mathrm{Yu}(1996)$ argue that the Heckman two-step estimator is effective even in the absence of an exclusion restriction in the selection equation, provided that at least one of the variables in the vector of covariates has enough variation to induce tail behavior in the inverse Mills ratio. As we will see, noncognitive ability is a strong predictor of participation in the labor market, suggesting that the Heckman two-step procedure could actually work for our purposes. Still, we view the results from Heckman two-step as a robustness check, not as our favoured specification.

We use as our fourth approach a simple variant of "identification at infinity" (Chamberlain, 1986; Heckman, 1990). The idea behind this identification strategy is to restrict the sample to a group of workers for whom the choice to select into the labor market is not affected by unobservable productivity $\left(\varepsilon_{i}\right)$. To this end, we first run a probit regression of an indicator variable of observable wages on $\left(c_{i}, n_{i}, \mathbf{X}_{i}\right)$ and then run regression (1) for men whose covariates imply a high predicted probability of nonmissing wages. A drawback with this method is that inferences may not be valid for the entire sample.

Table B2 reports the results from different approaches to control for selection bias. These results are not adjusted for measurement error and should thus be compared to the standard OLS estimates of column 1 in Table 1. We first show that the results are very similar for the two other wage measures described above. We then consider the three different methodological approaches starting with median regressions in column $3 .^{3}$ Second, we employ a simple variant of

\footnotetext{
${ }^{2}$ The only reason we choose such a high value as $10^{8}$ is to be certain that these wages are indeed above the conditional median.

${ }^{3}$ The results for median regression, Identification-at-infinity and Heckman two-step for the two sample with directly observable wages and the second measure of imputed wages are reported in Table A2.
} 
"identification at infinity" by first running a probit regression of the probability

of observed wages and then restricting the sample to men whose covariate values predicts this probability to be above 85 percent. Both quantile regression and "identification at infinity" give results close to the OLS estimates. Finally, column 5 gives the results from a Heckman two-step estimator. Even though these estimates are not corrected for measurement error, we find that the estimated effect of noncognitive ability is similar to the effect of cognitive ability already in the specification with the small set of covariates. However, as we do not have a credible exclusion restriction in the selection equation, these estimates should be interpreted with caution.

\subsection{Alternative samples and selection into the military service}

The main analysis in the paper is conducted on the core members in LINDA (which is representative of the Swedish population) with a number of restrictions (self-employed, students and workers in the agricultural sector are excluded). Table B3 gives summary statistics for those who excluded from the core sample and for family members in LINDA. Table B4 gives summary statistics for men (in the restricted core sample) depending on enlistment status. Table B5 gives results for wages and earnings for alternative samples. Table B6 presents regressions for enlistment into the military service and attrition (i.e., those who were enlisted but did not serve). The low number of observations in column (1) of Table B6 is due to missing information on health status. Figure B1 is a histogram over the age at the onset of the military service. We use data on the cash transfers conscripts receive while in the military to derive the age at the onset of the military service. This information allows us to observe which year the military service starts, but not the exact date, implying that there is some uncertainty as to the exact age.

\section{Appendix C: Measurement error}

There are several reasons to expect both our measures of cognitive and noncognitive skill to be measured with error. For example, motivation for the military service is likely to affect performance on the test of cognitive skill and in the enlistment interview. The score of noncognitive ability is also subject to a particular form of measurement error since psychologists vary in their assessment 
of identical conscripts. Lilieblad and Ståhlberg (1977) estimated the correlation between the SNSA psychologists' assessment of noncognitive skills to 0.85 after letting 30 SNSA psychologists listen to tape recordings of 30 enlistment interviews. ${ }^{4}$ In a bivariate regression, classical measurement error leads to a downward bias of the estimated strength of the relationship between two variables. This is not necessarily the case in a multivariate context. Since our skill measures are positively correlated (0.388), classical measurement error in one skill measure will imply a bias away from zero for the other skill measure.

Assuming classical measurement error, our measure of cognitive skills, $c$, is a function both of actual skills (denoted by $c^{*}$ ), and of a random error term, $v_{c}$. That is,

$$
c=c^{*}+v_{c}
$$

where $v_{c} \sim N\left(0, \sigma_{v_{c}}^{2}\right)$ and $\operatorname{Cov}\left(c^{*}, v_{c}\right)=0 .{ }^{5}$ We assume that the measurement error variance is the same across the entire population. We make the same assumptions regarding measurement error in noncognitive ability. Similar to Heckman et al. (2006), we thus view the measured level of cognitive and noncognitive ability as reflecting both true ability and measurement error. ${ }^{6}$ However, note that the "true" ability in this context refers to the cognitive and noncognitive abilities valued by the Swedish military. These abilities may not perfectly coincide with the abilities sought after by employers in the civilian labor market.

We use data from a sample of twins to calculate the reliability ratio of each skill measure. We use a method first proposed by Isacsson (1999) which in turn is based on a paper by Griliches (1979). Here, we illustrate this method in the case of cognitive skills but the argument is the same in the case of noncognitive skill. Assuming that the correlation in $v$ within twin pairs is zero, the correlation within MZ twins for $c$ is

$$
\rho_{M Z}=\frac{\sigma_{c_{1} c_{2}}}{\sigma_{c}^{2}}=\frac{\sigma_{c_{1}^{*} c_{2}^{*}}}{\sigma_{c^{*}}^{2}+\sigma_{v}^{2}}
$$

\footnotetext{
${ }^{4}$ Since all psychologist listen to the same interviews, this correlation is not an exact measure of the true correlation between psychologists' assessment. The fact that psychologists make their own interviews could, in theory, both imply that the true correlation is higher or lower than 0.85 .

${ }^{5}$ We further assume that all cross-moments between the true variables and the measurement errors are zero.

${ }^{6}$ Heckman et al. (2006) use a model with latent factor structure to adjust for measurement error. Our approach is different, as outlined below.
} 
where $\sigma_{c_{1}^{*} c_{2}^{*}}$ is the within-twin pair covariance in $c^{*}$. Without loss of generality, we can normalize the variance in $c$ to one, implying that

$$
\sigma_{c^{*}}^{2}+\sigma_{v}^{2}=1
$$

and

$$
\rho_{M Z}=\sigma_{c_{1}^{*} c_{2}^{*}} .
$$

Now consider the within-twin difference in observed cognitive skill

$$
\begin{aligned}
\Delta c & =\Delta c^{*}+\Delta v . \\
& =c_{1}^{*}-c_{2}^{*}+v_{1}-v_{2}
\end{aligned}
$$

Since $\sigma_{v_{1} v_{2}}=0$ by assumption, the variance in $\Delta c$ is

$$
2 \sigma_{c^{*}}^{2}-2 \sigma_{c_{1}^{*} c_{2}^{*}}+2 \sigma_{v}^{2}
$$

implying that the reliability ratio for cognitive skills within MZ twin pairs is

$$
\frac{\sigma_{c^{*}}^{2}-\sigma_{c_{1}^{*} c_{2}^{*}}}{\sigma_{c^{*}}^{2}-\sigma_{c_{1}^{*} c_{2}^{*}}+\sigma_{v}^{2}}
$$

which can also be expressed as

$$
\begin{aligned}
& \frac{\sigma_{c^{*}}^{2}-\rho_{M Z}}{\sigma_{c^{*}}^{2}+\sigma_{v}^{2}-\rho_{M Z}} \\
= & \frac{\sigma_{c^{*}}^{2}-\rho_{M Z}}{1-\rho_{M Z}} .
\end{aligned}
$$

Now consider the regression

$$
\Delta y_{M Z}=\beta_{M Z} \Delta c_{M Z}^{*}+\varepsilon
$$

where $\Delta y_{M Z}$ is the difference in some outcome (in our case annual earnings) within monozygotic (identical) twin pairs, and $\Delta c_{M Z}^{*}$ the corresponding difference in true cognitive skill. By regressing $\Delta y_{M Z}$ on $\Delta c_{M Z}$ (the observed within 
twin-pair difference in cognitive skill), we obtain an estimate of $\beta_{M Z}{ }^{7}$

$$
\widetilde{\beta}_{M Z}=\left(\frac{\sigma_{c^{*}}^{2}-\rho_{M Z}}{1-\rho_{M Z}}\right) \beta_{M Z}
$$

Rearranging this expression gives

$$
\sigma_{c^{*}}^{2}=\left(1-\rho_{M Z}\right) \frac{\widetilde{\beta}_{M Z}}{\beta_{M Z}}+\rho_{M Z}
$$

or, equivalently

$$
\frac{\sigma_{c^{*}}^{2}}{\sigma_{c^{*}}^{2}+\sigma_{v}^{2}}=\left(1-\rho_{M Z}\right) \frac{\widetilde{\beta}_{M Z}}{\beta_{M Z}}+\rho_{M Z}
$$

We can thus express the reliability ratio for cognitive ability as the sum of two terms: the correlation in observed test scores between MZ twins $\left(\rho_{M Z}\right)$ plus $1-\rho_{M Z}$ multiplied by a factor $\left(\widetilde{\beta}_{M Z} / \beta_{M Z}\right)$. The ratio $\widetilde{\beta}_{M Z} / \beta_{M Z}$ denotes the share of the within-twin variance in measured cognitive skill that reflect true differences in skill. We observe $\rho_{M Z}$ and $\widetilde{\beta}_{M Z}$ but not $\beta_{M Z}$. To get an estimate of $\beta_{M Z}$, note that we get an analogous expression for dizygotic (fraternal) twins. That is, the estimates from the regression

$$
\Delta y_{D Z}=\beta_{D Z} \Delta c_{D Z}^{*}+\varepsilon^{\prime}
$$

together with the within-twin correlation give the reliability ratio

$$
\frac{\sigma_{c^{*}}^{2}}{\sigma_{c^{*}}^{2}+\sigma_{v}^{2}}=\frac{\widetilde{\beta}_{D Z}}{\beta_{D Z}}\left(1-\rho_{D Z}\right)+\rho_{D Z}
$$

Consequently,

$$
\frac{\widetilde{\beta}_{M Z}}{\beta_{M Z}}\left(1-\rho_{M Z}\right)+\rho_{M Z}=\frac{\widetilde{\beta}_{D Z}}{\beta_{D Z}}\left(1-\rho_{D Z}\right)+\rho_{D Z} .
$$

Now, assuming that the true effects are the same for DZ and MZ twins, i.e., $\beta_{M Z}=\beta_{D Z}$, we get

$$
\beta_{D Z}=\beta_{M Z}=\frac{\widetilde{\beta}_{D Z}\left(1-\rho_{D Z}\right)-\widetilde{\beta}_{M Z}\left(1-\rho_{M Z}\right)}{\rho_{M Z}-\rho_{D Z}} .
$$

Let $\beta_{D Z}=\beta_{M Z}$ be denoted by $\beta$. Once we have obtained $\beta$, the reliability

\footnotetext{
${ }^{7}$ Note that the parameter $\beta_{M Z}$ does not have a causal interpretation as differences between twins in cognitive ability are likely to be correlated with other factors that enhance earnings.
} 
ratio is identified.

Estimates of the parameters $\left(\widetilde{\beta}_{M Z}, \rho_{M Z}, \widetilde{\beta}_{D Z}, \rho_{D Z}\right)$ have been provided to us by David Cesarini based on a sample from the Swedish Twin Registry restricted to the cohorts which are relevant in our case. ${ }^{8}$ This sample covers 701 twin pairs with data on annual earnings and the enlistment skill measures. ${ }^{9}$ From an OLS on annual earnings, we get for the noncognitive measure

$$
\begin{aligned}
\beta & =\frac{36569(1-0.5217)-2338(1-0.6953)}{0.6953-0.5217} \\
& =96651
\end{aligned}
$$

This gives us an reliability ratio for noncognitive skills which is

$$
\frac{\widetilde{\beta}_{M Z}}{\beta}\left(1-\rho_{M Z}\right)+\rho_{M Z}=\frac{2338}{96651}(1-0.6953)+0.6953=0.70267
$$

Using the same formula and corresponding data for cognitive skills, we get

$$
\begin{aligned}
\beta & =\frac{14829(1-0.5027)-6796(1-0.8004)}{0.8004-0.5027} \\
& =20215
\end{aligned}
$$

We then get the reliability ratio

$$
\begin{aligned}
\frac{\widetilde{\beta}_{M Z}}{\beta}\left(1-\rho_{M Z}\right)+\rho_{M Z} & =\frac{6796}{20215}(1-0.8004)+0.8004 \\
& =0.8675
\end{aligned}
$$

Note that the lower reliability ratio for noncognitive ability is consistent with the lack of perfect congruence between the assessment of different psychologists. Using the estimated reliability ratios and assuming zero covariance between measurement errors, it is straightforward to adjust for measurement error. ${ }^{10}$

It should be noted, however, that our derivation of reliability ratios and measurement error correction relies on a number of quite strong assumptions.

\footnotetext{
${ }^{8}$ The parameters are estimated by OLS regressions with annual earnings as the dependent variable. The results are very similar when we instead consider the log of annual earnings as the dependent variable.

${ }^{9}$ The twins in the Swedish Twin Registry data (both monozygotic and dizygotic) are somewhat positively selected in terms if cognitive and noncognitive ability compared to our sample (about .25 standard deviations for each measure). About $3 \%$ of the twins from the Swedish Twin Registry can be presumed to be present in our data.

${ }^{10} \mathrm{We}$ adjust for measurement error using Stata's [eivreg] command. For a textbook treatment of this method, see Kmenta (1997) or Draper and Smith (1998).
} 
If measurement errors are positively correlated between twins (which seems likely) we would overestimate the reliability ratios, creating a bias toward zero in the estimated effect of cognitive and noncognitive skills. Another important assumption is that there is no correlation between measurement errors in cognitive and noncognitive skills for a given conscript. Though we cannot test this assumptions, it seems plausible that there is some positive correlation in measurement errors.

\section{Appendix D: Additional results}

This Appendix presents various additional results. First, we present results from a nonparametric estimation of wages that shows the positive interaction effect between cognitive and noncognitive ability. We let each unique value of cognitive and noncognitive ability be represented by a dummy variable and estimate the effect of each skill measure on log wages while fixing the opposite skill measure at low (1-3 on the 1-9 scale), medium (4-6) or high values (7-9). We exclude skill combinations for which there are fewer than 100 observations and normalize the effect to zero for the lowest skill value which is included in the regression. As shown in Figure Figure D1, the return to noncognitive ability is higher for men with high cognitive ability than for men with low or average values of cognitive ability. Correspondingly, Figure D2 shows that the effect of cognitive ability is larger for men with high noncognitive ability. 
Figure D1 and D2. Ability and Log Wages
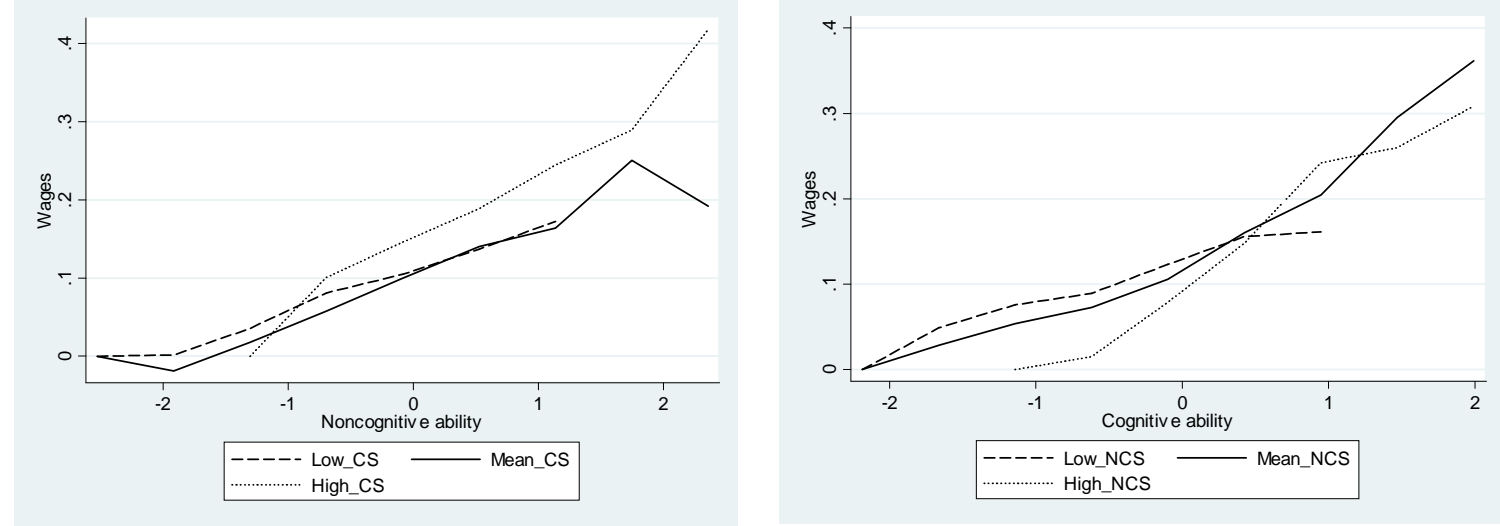

Samples restricted to "low" (1-3), "mean" (4-6) or "high" (7-9) values of the corresponding skill measure. All regressions include fixed effects for each value of cognitive and noncognitive skill included in the specific sample and the "small" set of covariates as defined in Table 1. Sample restricted to skill combinations with at least 100 observations. Effect normalized to zero for the lowest value included in the regression.

Table D1 gives the results for unemployment and earnings when controlling for the large set of covariates or adjusting for measurement error. Table D2 and D3 give the point estimates underlying Figure 2 and 3 in the paper. In the figures, we transform the estimates by dividing by annual earnings at each percentile. We use the Stata program rifreg which is downloadable from Nicole M. Fortin's homepage ${ }^{11}$ to estimate the unconditional quantiles.

Table D4 presents robustness tests for potential omitted variables.

First, we control for type of military service in column (1). The argument for including type of military service as a control variable is that test scores have a direct effect on the type of military training to which conscripts are enlisted. To the extent that the type of military service affects future wages, not including type of military service as a covariate in $\mathbf{X}_{i}$ implies undercontrolling. However, though the military service itself is mandatory, conscripts have some freedom to affect the position they are assigned to, provided that they fulfill the specific requirements for this position. Hence, the fact that a conscript with a high score on noncognitive and cognitive skill was not enlisted into a leadership position is

\footnotetext{
${ }^{11}$ http://www.econ.ubc.ca/nfortin/hmpgfort.htm
} 
a signal of an unwillingness to assume responsibility. Consequently, controlling for type of position implies that the identifying variation in our ability measures is in fact correlated with an aspect of personality that can be presumed to have a negative effect on outcomes, creating a bias toward zero. For this reason, we have chosen only to include a dummy for enlistment into the military service in the basic specifications. As shown in Table D4, controlling for type of military service decreases the estimated effects of noncognitive and cognitive ability as one would expect. In contrast, the effect of cognitive and noncognitive ability on unemployment is strengthened somewhat when controlling for type of military service (results available upon request).

Another potential concern is that the measure of noncognitive skills functions as a proxy for health status, which might have an independent effect on outcomes. There is, indeed, a positive correlation between noncognitive skill and health status classification at the enlistment in our data. In comparison, the correlation between cognitive skill and health status is much weaker. ${ }^{12}$ However, as shown in columns 2 and 3, controlling for health status does not change the results appreciably once we restrict the sample to men for whom health status is observed. As evidence of psychopathology give conscripts a low health ranking (in addition to a low rating on noncognitive ability), the fact that our results are insensitive to controlling for health status also ensures that they are not driven by a few men with mental health problems.

Finally, we show in Table D4 that our results for wages remain essentially the same when controlling for age at draft (column 4).

\section{Appendix E: Occupational choice}

We use the information on occupation LINDA contains information on occupation to assign workers into three broad occupation groups (SSYK 96): managers, skilled workers and unskilled workers. We use the ten broadest occupational categories in the data, numbered from 0-9. We exclude men in group 0 (military work) and define group 1 (managerial work) as "managers". Group 2-9 has a qualification level attached to them (group 0 and group 1 are not assigned a qualification level), and we use this to classify workers as "skilled" or "unskilled". The qualification level goes from 1 (lowest) to 4 (highest). We define workers in group 2 (qualification level 4) and group 3 (qualification level 3) as

\footnotetext{
${ }^{12}$ A regression of noncognitive ability on the full set of dummy variables for health status classifications has an $R^{2}$ of .2361 compared to .0496 for cognitive ability.
} 
"skilled", while workers in group 4-8 (qualification level 2) and 9 (qualification level 1) are defined as "unskilled".

Table E1 gives the marginal effects from a multinomial logit of occupational choice on $\left(c_{i}, n_{i}, \mathbf{X}_{i}\right)$. In the specification with the small set of control variables, high cognitive skills is a strong predictor of selection into a skilled occupation, while men with low cognitive skills are more likely to select into a unskilled occupation. This pattern remains the same when education and experience are controlled for, though it is less pronounced. Men with high noncognitive skills are more likely to become managers or work in skilled occupations than workers with low noncognitive skills. The predictive power of noncognitive skills on occupational choice is insensitive to controlling for educational attainment.

We now turn to an estimation of the returns to skills across occupational groups. The key econometric problem in this estimation is that we only observe the wage in a given occupation for men who have selected into this occupation. For example, we do not observe the wage that managers would earn as skilled workers, and vice versa. If unobserved factors that influence occupational choice are also correlated with productivity in different occupations, then self-selection may bias our estimated skill prices.

More formally, we want to estimate the model

$$
\log w_{i j}=\beta_{c, j} c_{i}+\beta_{n, j} n_{i}+\mathbf{X}_{i} \gamma_{j}+\varepsilon_{i j}
$$

where $j=\{$ manager, skilled, unskilled $\}$. The econometric problem is that $w_{i j}$ is only observed in case person $i$ chooses occupation $j$. Let

$$
w_{i j}^{*}=\mathbf{z}_{i} \boldsymbol{\delta}_{j}+\eta_{i j}
$$

denote the utility individual $i$ attaches to working in occupation $j$. Each individual chooses the occupation that maximizes his utility. For example, we only observe wages in unskilled occupations in case

$$
w_{\text {unskilled }}^{*}>\max _{j \neq \text { unskilled }}\left(w_{j}^{*}\right) .
$$

McFadden (1973) showed that the model above leads to the multinomial logit model in case the error terms in the choice equations are independent and identically Gumbel distributed. Lee (1983) proposed a procedure to correct for selection bias in the multinomial case which is essentially an application of the Heckman (1979) selection model. Bourguignon et al. (2007) argue that the Lee 
(1983) procedure imposes strong assumption on the covariances between the error terms in the selection and the outcome equations. Instead, they propose an alternative estimator based on Dubin-McFadden (1984) but which allows for more general distributions for $\varepsilon_{i j}$, in particular the normal distribution. We consider both of these estimators. ${ }^{13}$

We use as instruments in the selection equation region of residence in 1980 and dummy variables for whether mother and father worked in a white-collar occupation in 1980. As there is no direct information on occupation available in the 1980 wave of LINDA, we use industry code (SNI69) of occupation as a proxy for occupation. This code is very detailed (five-digits), but we use the first two digits which indicate industry in a broader sense. We classify parents working in postal services and telecommunications; banking and finance; insurance; administration and consulting; public administration; education and culture as "white collar" and parents working in forestry; fishing; mining; readymade clothing; pulp; chemical industries; other types manufacturing; energy; construction; retail; tourism; transportation; water and sanitation and repair services as "blue-collar".

Our identifying assumptions are thus that, controlling for parental income and $\left(c_{i}, n_{i}, \mathbf{X}_{i}\right)$, parents' occupational status and region of residence in 1980 will affect occupational choices only through preferences for different types of jobs. For example, children whose parents worked in a white-collar job could have a higher utility in white-collar jobs, but are not more productive once we include our full set of covariates and measures of cognitive and noncognitive skills. Since we do not observe occupational choice for all the men in the data, we include a fourth category of "no data on occupation" in the selection equation.

The estimated occupation-specific skill prices are displayed in Table E2. In general, the estimated skill prices are consistent with the more pronounced convexity in the return to cognitive skills and the selection patterns documented in Table 2. Noncognitive ability has a higher return than cognitive ability for managers and workers in unskilled occupations while workers in skilled occupations have a return to cognitive skill similar to the return to noncognitive skill.

\footnotetext{
${ }^{13}$ All estimations based on multinomial logit are conducted with the Stata selmlog command developed by Bourguignon et al. (2007).
} 


\section{Appendix F: Skill measures}

This section provides additional material regarding our skill measures. We first present some historical background. We then present results for wages when using the sum of subscores instead of the normalized final (1-9) scores and when using each subscore separately. We also run the basic wage regression with residualized ability measures and test whether psychologists are influenced by their knowledge of the conscript's cognitive test score. The third subsection gives additional information regarding the test of cognitive skills, including definitions of the cognitive skill subtest. Finally, we provide a summary of an old manual for the enlistment interview. This manual regards the assessment of leadership ability which is different from the measure of general military aptitude we use as our noncognitive ability measure in the paper.

\subsection{Historical background}

The use of extensive psychological tests at the Swedish military enlistment took off in the early 1940's and were led by Torsten Husén. In 1942, a wide range of tests was conducted on an entire cohort of conscripts (32,000 men) with the aim of acquiring expertise on how to conduct psychological tests (Husén 1942c). There were tests of cognitive ability, physical fitness, but also of willpower and power of initiative. The reliability of each test was then evaluated by correlating the test scores with the commanding officer's assessment of the conscripts' military skills at various stages of the military service. Based on these experiences, a test of cognitive ability was introduced in 1944 together with more extensive tests of personality for applicants to the military academies (Husén 1946). By 1950, psychological stability and ability to adjust to the military environment were assessed for the majority of conscripts in a 10-20 minute interview (Husén 1951).

Husén recognized already at an early stage that selection into the military service must be based both on an assessment of constripts' intelligence and their character (Husén 1942b). For example, Husén emphasized the important role of emotional stability (1942a) for success in the military. Another common theme in Huséns early writings is that men will bring their personality in civilian

life into the military service. For example, Husén (1946) emphasizes that men who have difficulties adjusting to their civilian environment will only see these difficulties magnify while in the military. The focus on avoiding the martial 
misfits, like neurotics and psychopaths, is also present in Husén writings from the 1940's. Husén (1946) argues forcefully that the military service itself is unlikely to change men to the better. Men with an anti-social personality will, if anything, become more anti-social. Neurotic men will see their symptoms worsened, etc. In a large study of conscripts' with particular discipline problems, Husén (1951) argues that a substantial share of indiscipline conscripts exhibit problems adjusting to also to civilian life.

As described in the paper, the procedure to evaluate conscripts that we consider was introduced in the early 1970's. This procedure was then kept unchanged until 1995 when minor modifications were undertaken. The educational requirements for the psychologists have increased over time. As of the mid-1970's, most psychologists had a bachelor's degree (Lilieblad and Ståhlberg 1977). Psychologists also have to undergo a four-week course prior to working for the SNSA. Evaluation of the predictive power of the psycholigists' assessment for conscripts' success in the military service has continued. Carlstedt (1999) shows that the score on military aptitude has predicted power for the commanding officers' assessment of conscripts' skills after completion of the military service.

\subsection{Additional analysis}

As an alternative measure of cognitive ability, we percentile rank-transform the sum of subscores. We then convert it by taking the inverse of the standard normal distribution to produce normally distributed test scores. We present the results from wage regressions using these measure is Table F1. The results do not differ appreciably from those in Table 1.

Let us now consider each subscore separately. Table F2 shows that the pairwise correlations between our cognitive subscores range from 0.50 to 0.68. Table F3 shows the results from a regression of log wages on each cognitive ability subscore and the small set of covariates. The effect sizes are similar for all measures except mental rotation (a test of spatial ability) which is somewhat less strongly correlated with wages than the other measures. Including all measures in a single regression (column 5) leads only to a modest increase in variance explained. Table F4 presents the correlations between the noncognitive ability subscores. The correlations vary between 0.46 and 0.63 . The results in wage regressions with each noncognitive subscore are presented in Table F5. Except for the second measure, which has a weaker association with wages, the esti- 
mated effects of these measures are very similar. Including all subscores jointly has only a modest effect on variance explained.

Table F6 presents results for the basic wage regression when using residualized ability measures. The first column presents the case when we use the residuals from a regression of noncognitive ability on cognitive ability as our measure of noncognitive ability. The point estimate of this measure is identical to the point estimate in column (1) of Table 1. The results for the non-residualized measure of cognitive ability is somewhat stronger than the corresponding result in Table 1 (column 5). Similarly, using a residualized measure for cognitive ability gives a somewhat stronger effect for noncognitive ability than just dropping cognitive ability from the regression (column 6, Table 1).

Finally, we use the entire draft data set for 1983-1993 to estimate the effect of the cognitive score on the psychologists' assessment of noncognitive ability. To control for underlying intelligence, we interact a fifth-order polynomial in the sum of subscores (4-36) with enlistment year. Our results, presented in Table F7, indicate that an increase by one step on the 1-9 cognitive test score scale increases the assessed level of noncognitive ability by 0.109 on the 1-9 scale, implying that the covariance between cognitive and noncognitive should in part be attributed to an effect of cognitive skills on estimated noncognitive ability. However, simulations show that this effect alone can only account for a small part of the total covariance: The effect of the cognitive score on the noncognitive would give a correlation of about 0.11 if it were the only source of covariance.

\subsection{Additional information regarding the test of cognitive skills}

The test of cognitive ability consists of 4 subtests with 40 questions each. The number of correct answers to these question gives a subscore grade set on 1-9 scale, the sum of which (i.e., 4-36) gives the final score on cognitive ability set on a 1-9 Stantine scale. The ideal Stantine distribution (with \% of population in parentheses) is: 1 (4); 2 (7); 3 (12); 4 (17); 5 (20); 6 (17); 7 (12); 8 (7); 9 (4). We use the same normalization for all cohorts even though the exact mapping from the scores on each subtest to general cognitive ability has changed slightly over the years. The reason is that we lack data on enlistment year for 141 observation. The correlation between a normalization for all cohorts and a normalization by enlistment year is .999 for cognitive ability and .998 for noncognitive ability.

Definitions of the cognitive skill subtests are provided by Carlstedt and 
Mårdberg (1993, p. 355): "The Enlistment Battery is a paper and pencil test. The answers are marked on separate optical answering sheets. Each test consists of 40 items presented in increasing order of difficulty. The tests are slightly speeded.

The Enlistment Battery contains the following four tests:

Instructions (Test A). The first test of the battery, Instructions, contains verbally formulated instructions to make markings on an answering sheet that fulfill the conditions given by the instructions. 'The main principle for solving the item tasks is that it should be possible to solve them from the information given for each item. Difficulty is varied by the complexity of the instructions and by distractive negations or conditional clauses. In some of the items simple numerical operations are parts of the logical sequences. The test is meant to measure the combined ability of problem solving, induction capacity, and numerical ability' (Ståhlberg Carlstedt \& Skold, 1981, p. 5). Thus, this test was designed to measure the primary factor Induction.

Synomyms (Test B). For each item of this test a target word is presented and the correct synonym should be chosen among four alternatives. The test is meant to measure the primary factor Verbal Comprehension.

Metal folding (Test C). Each task of this test is to find one three-dimensional object out of four that corresponds to a two-dimensional drawing of an unfolded piece of metal. The test was designed to measure the primary factor Spatial Ability.

Technical Comprehension (Test D). The items of this test all constitute illustrated technical and physical problems. One out of three solutions should be marked as the proper one. The test was constructed to measure a Technical Comprehension factor."

\subsection{The interview procedure in the 1960's}

Before 1969, the objective of the enlistment interview was to assess leadership ability for conscripts with high cognitive ability. The guidelines for this interview are no longer confidential (Militarpsykologiska institutet, 1956; Mili-

tarpsykologiska institutet, 1964). We provide a description of these guidelines below, which we hope will provide some context to the enlistment interview.

However, we want to emphasize that these guidelines should not be taken as a literal description of the assessment of "general military aptitude", which we use as our measure of noncognitive ability. The subscores underlying the leadership 
score are different from those underlying the score on military aptitude. Another key difference is that while the psychologists are instructed to take cognitive ability explicitly into account when assessing leadership ability, this is not the case for military aptitude.

The reason we choose the general aptitude score as our noncognitive measure, rather than the leadership measure, is that it is available for the entire sample and has a lower correlation with cognitive ability. We have, however, run our main regressions also for leadership ability and found that the results are almost exactly the same as for military aptitude.

\subsubsection{Purpose and overall setting}

The guidelines from the 1950's and 1960's state that approximately $60 \%$ of the draftees should be evaluated with respect to the ability to assume leadership in the military, which at the time was the primary purpose of the interview. The guidelines do however indicate that a second purpose is to judge whether a draftee is at all suitable for military training and a position in the military. Reasons for being unsuitable could for instance be lack of cognitive ability or signs of emotional instability.

The guidelines ask the interviewer to use on average 15 minutes per interview. The interview should be conducted in a separate room. As background information, the interviewer has school grades, general information about civil status, job experience, results from a questionnaire with open-ended answers, results from a multiple-choice questionnaire and the result from the test of cognitive skill.

\subsubsection{The interviewer's role and communication style}

The interviewer is reminded that the draftee may want to manipulate the outcome of the interview. To limit the effect of such attempts, the interviewer is asked to ignore the draftee's motivation for armed service per se and focus on the relevant personal factors. The guidelines do, however, state that motivation has been shown to correlate with fundamentally relevant factors. The interviewer should use a civilian tone and manner and is asked to convey the impression that one purpose of the interview is to be helpful rather than to screen draftees in terms of skills. For instance, advice on school choices or

seemingly suitable civilian career paths may be given to draftee. Although time is short, the interviewer should not abruptly interrupt the draftee. Further, the 
guidelines states that the interview should be kept as a conversation with the use of a neutral language, without the use of leading questions or condemning language. The interviewer should avoid to advise the draftee on specific suitable military positions.

\subsubsection{Factors for the evaluation}

Five areas of the draftee's personal life must be covered during the interview. The interviewer grades the draftee on a 1-5 scale on each factor. On average, cognitive skill is expected to correlate with these scores, in particular at the lower end of cognitive skill distribution. The first topic is the draftee's experience from school. Aside from the academic achievements of the draftee, it is of interest to investigate how the draftee adapted to the school environment and his own perception of his school experience. Examples of noteworthy behavior are school quits, drop-outs or whether some classes were repeated.

The second topic is work experience. Of main interest is the draftee's ability to function in the workplace. Examples of noteworthy events are repeated conflicts with managers or co-workers, whether the draftee had been fired or quit abruptly, etc. If the draftee has limited or no work experience, the interviewer should base his judgment on the draftee's career plans - whether such exist, whether they seem realistic, etc.

The third topic is how the draftee spends his leisure time. It is of interest whether the draftee is active and passionate about a hobby and to which extent the draftee has shown sustained interest in certain activities. Further, it is of interest whether the activities show tendency for extroversion or introversion,

whether he participates in team sports, whether he seems to have rich interests and if there are signs that the draftee is able to adopt to given circumstances. Of particular interest are leadership roles. A mandatory question when covering this topic is 'What do you think of your ability to lead a group of peers?'.

The fourth topic is home environment and upbringing. Of particular interest are contacts with parents and siblings. Rather than judging the home conditions objectively, the interviewer is instructed to make notes of the draftee's subjective experience of the conditions, to investigate how the draftee may have adopted to difficult circumstances and to which extent the draftee is excessively dependent on his parents. A mandatory question is 'How often do you use alcohol?'.

The fifth topic of the interview is emotional stability. Apart from issues that may have been raised during the conversation, the interviewer is asked 
to base the conversation on answers from the multiple-choice questionnaire if these answers indicate negative behavior. Overall, the draftee's maturity and self-knowledge is of interest.

\section{References}

Bloomfield, P. and Steiger, W. L. (1983), Least Absolute Deviations: Theory, Applications, and Algorithms, Boston: Birkhauser

Bourguignon F., Fournier, M., Gurgand M. (2007), "Selection Bias Corrections Based on the Multinomial Logit Model: Monte-Carlo Comparisons", Journal of Economic Surveys, 21(1), 174-205.

Carlstedt, B. and Mårdberg, B. (1993), "Construct Validity of the Swedish Enlistment Battery", Scandinavian Journal of Psychology, 34(4), 353-362.

Carlstedt, B. (1999), Validering av inskrivningsprövning mot vitsord från den militära grundutbildningen, Försvarshögskolan, Serie T:11.

Chamberlain, G. (1986), "Asymptotic Efficiency in Semiparametric Models with Censoring", Journal of Econometrics, 32(Spring), 189-218.

Draper N.R. and Smith, H. (1998), Applied Regression Analysis, Wiley-Interscience.

Dubin, J. A. and McFadden, D. L. (1984) "An econometric analysis of residual electric appliance holdings and consumption", Econometrica 52, 345-362.

Griliches, Z. (1979), "Sibling Models and Data in Economics: Beginnings of a Survey", Journal of Political Economy, 87(5), S37-S64.

Gronau, R. (1974) "Wage Comparisons - A Selectivity Bias", Journal of Political Economy 82, 1119-1143.

Heckman, J. (1976) "The Common Structure of Statistical Models of Truncation, Sample Selection, and Limited Dependent Variables and a Simple Estimator for Such Models", Annals of Economic and Social Measurement 5, 475-492.

Heckman, J. (1979) "Sample Selection Bias as Specification Error", Econometrica 47, 153-161. 
Heckman J. (1990), "Varieties of Selection Bias", American Economic Review 80(2), 313-318.

Heckman J., Stixrud, J., Urzua, S. (2006), "The Effects of Cognitive and Noncognitive Abilities on Labor Market Outcomes and Social Behavior", Journal of Labor Economics 24(3), 411-482.

Husén, Torsten. 1942a. "Den militära paniken." Ny militär tidskrift, vol. 15, no. 5-6: 105-109.

Husén, Torsten. 1942b. "Militära lämplighetsprov. Vad kunna de ge?" Ny militär tidskrift, vol. 15, no. 13-14: 10-15.

Husén, Torsten. 1942c. "Provverksamhetens uppläggning samt bearbetning av provresultaten." Kung. Krigsvetenskapsakademiens handlingar och tidskrift, vol. 146 , bihäfte 4: 12-74.

Husén, Torsten. 1946. "Militär psykologi." in SOU 1946:75: 287-301.

Husén, Torsten. 1951. "De indisciplinära värnpliktiga." in Social årsbok 195051: 134-188.

Isacsson, G. 1999. "Estimates from the Return to Schooling in Sweden from a Large Sample of Twins" Labor Economics, 6(4): 771-489.

Kmenta, J. (1997), Elements of Econometrics (2nd ed), The University of Michigan Press.

Lee, L. F. (1983) "Generalized econometric models with selectivity", Econometrica 51, 507-512.

Lilieblad, B. and Ståhlberg, B. (1977), Reliabilitet hos psykologiska bedömningar vid inskrivningsprövning, FOA-rapport C 55011-H7.

McFadden, D. L. (1973), "Conditional logit analysis of qualitative choice behavior", in P. Zarembka (ed.), Frontiers in Econometrics,New York: Academic Press 
Lee, L. F. (1983), "Generalized econometric models with selectivity", Econometrica $51,507-512$

Leung, S. F. and Yu, S. (1996), "On the choice between sample selection and two-part models", Journal of Econometrics, vol. 72, 197-229

Militarpsykologiska inst (1956), "Instruktion för exploratörer vid inskrivning (IExplor)", 6. uppl.

Militarpsykologiska inst (1964), "Instruktion för exploratörer vid inskrivningsförrättning (IExplor)"

Neal, D. A. and Johnson, W. R. (1996), "The Role of Premarket Factors in Black-White Wage Differences", Journal of Political Economy 104 (October), 869-895.

Neal, D. A. (2004), "The Measured Black-White Wage Gap Among Women Is Too Small", Journal of Political Economy, February vol. 112, 1-28

Olivetti, C. and Petrongolo, B. (2008), "Unequal pay or unequal employment? A cross-country analysis of gender gaps", Journal of Labor Economics, 26(4), $621-654$

Silverman, B. W. (1986), Density Estimation for Statistics and Data Analysis, London: Chapman \& Hall.

Stahlberg Carlstedt, B. and Skold, P. (1981), "Inskrivningsprov 80 - Testmanual", National Defense Research Establishment Report no. CH 55001-H7 
Table B1: Summary statistics for additional variables used in Appendix B-F (core sample)

\begin{tabular}{lcccl}
\hline Variable & Obs & Mean & Std. Dev. & Comment \\
\hline Wage in 2006 (W1) & 12570 & 28442 & 12202 & \\
Imputed wage 2 (W3) & 14703 & 27679 & 11887 & Missing wages imputed from earnings \\
Cognitive skill measure based on sum of subscores & 13173 & .000 & .996 & Based on 4-36 scale \\
Noncognitive skill measure based on sum of subscores & 11960 & .000 & .985 & Based on 4-20 scale \\
Enlisted as squad leader & 14703 & 0.204 & & \\
Enlisted as platoon leader & 14703 & 0.088 & & \\
Family background: Father white-collar worker & 10771 & 0.321 & & Coded from industry data \\
Family background: Mother white-collar worker & 10886 & 0.680 & & Coded from industry data \\
Cognitive subscore 1: Logic ability & 13278 & 5.19 & 1.94 & \\
Cognitive subscore 2: Verbal ability & 13439 & 4.99 & 1.76 & \\
Cognitive subscore 3: Technological comprehension & 13505 & 5.08 & 1.84 & \\
Cognitive subscore 4: Metal folding & 13439 & 5.22 & 1.92 & \\
Noncognitive subscore 1 & 12011 & 3.14 & 0.72 & \\
Noncognitive subscore 2 & 11999 & 2.94 & 0.87 & \\
Noncognitive subscore 3 & 12007 & 3.15 & 0.68 & \\
Noncognitive subscore 4 & 11997 & 3.03 & 0.67 & \\
\hline
\end{tabular}

Table B2: Controlling for selection bias in regression of log wages

\begin{tabular}{|c|c|c|c|c|c|c|}
\hline & (1) OLS & (2 OLS & (3 Median & (4) IAI & \multicolumn{2}{|c|}{ (5) Heckman two-step } \\
\hline Wage measure & W1 & W3 & W2q & W2 & W2 & Select \\
\hline \multirow[t]{2}{*}{ Cognitive skills } & $0.086^{\star \star *}$ & $0.082^{\star \star \star}$ & $0.083^{* \star *}$ & $0.092^{* \star *}$ & $0.088^{* \star *}$ & 0.022 \\
\hline & $(0.003)$ & $(0.003)$ & $(0.003)$ & $(0.003)$ & $(0.006)$ & $(0.021)$ \\
\hline \multirow[t]{2}{*}{ Noncognitive skills } & $0.065^{\star * *}$ & $0.067^{\star \star \star}$ & $0.059^{* * *}$ & $0.071^{* * *}$ & $0.085^{\star \star *}$ & $0.196^{\star * *}$ \\
\hline & $(0.003)$ & $(0.003)$ & $(0.003)$ & $(0.003)$ & $(0.012)$ & (0.022) \\
\hline Observations & 12545 & 14626 & 14626 & 13760 & 14626 & 14626 \\
\hline R-squared & 0.298 & 0.290 & & 0.279 & & \\
\hline
\end{tabular}

Heteroskedasticity-robust standard errors are reported in parenthesis in columns (1)-(2) and (4).

Standard errors in column (4) computed with bootstrap ( 20 replications). All regressions include the small set of covariates. See Table 1 for more information. 
Table B3: Summary statistics for non-core sample

\begin{tabular}{llcc}
\hline Sample & Variable & Obs & Mean \\
\hline Excluded from core sample* & Cognitive ability & 1179 & -0.014 \\
& $\begin{array}{l}\text { Noncognitive ability } \\
\text { Earnings in 2006 }\end{array}$ & 1179 & -0.069 \\
& & 1179 & 135,300 \\
Family sample - restricted** & & \\
& $\begin{array}{l}\text { Cognitive ability } \\
\text { Noncognitive ability }\end{array}$ & 24,918 & 0.053 \\
& Earnings in 2006 & 24,918 & 0.130 \\
& 24,918 & 341,800 \\
\hline *Excluded due to student status, self-employment or work in agricultural sector \\
**The "restricted" sample excludes self-employed, workers in the agricultural \\
sector and students
\end{tabular}

Table B4: Summary statistics by enlistment status (core sample)

\begin{tabular}{llcc}
\hline Sample & Variable & Obs & Mean \\
\hline Enlisted & Cognitive ability & 13,228 & 0.05 \\
& Noncognitive ability & 13,228 & 0.11 \\
& Earnings in 2006 & 13,228 & 327,300 \\
& & & \\
Not enlisted & Cognitive ability & 1,475 & -0.45 \\
& Noncognitive ability & 1,475 & -1.03 \\
& Earnings in 2006 & 1,475 & 252,400 \\
\hline
\end{tabular}


Table B5: Regression results for alternative samples

\begin{tabular}{|c|c|c|c|c|c|c|c|c|}
\hline & (1) & (2) & (3) & (4) & (5) & (6) & (7) & (8) \\
\hline Dependent variable & $\begin{array}{c}\text { Annual } \\
\text { earnings }\end{array}$ & $\begin{array}{l}\text { Log wages } \\
\text { (W2) }\end{array}$ & $\begin{array}{c}\text { Annual } \\
\text { earnings }\end{array}$ & $\begin{array}{l}\text { Log wages } \\
\text { (W1) }\end{array}$ & $\begin{array}{l}\text { Log wages } \\
\text { (W1) }\end{array}$ & $\begin{array}{l}\text { Log wages } \\
\text { (W1) }\end{array}$ & $\begin{array}{c}\text { Annual } \\
\text { earnings }\end{array}$ & $\begin{array}{l}\text { Log wages } \\
\text { (W2) }\end{array}$ \\
\hline \multirow[t]{2}{*}{ Cognitive skills } & $31,359^{\star \star *}$ & $0.083^{* \star *}$ & $37,769^{* \star *}$ & $0.100^{\star * \star}$ & $0.101^{\star \star *}$ & $0.089^{* \star *}$ & $33,781^{* * *}$ & 0.087 \\
\hline & $(1,724)$ & $(0.003)$ & $(1,452)$ & $(0.003)$ & $(0.003)$ & $(0.002)$ & $(1,461)$ & $(0.003)$ \\
\hline \multirow[t]{2}{*}{ Noncognitive skills } & $35,826^{\star * *}$ & $0.065^{\star * *}$ & $41,401^{* * *}$ & $0.065^{* * *}$ & $0.056^{* * *}$ & $0.065^{* * *}$ & $37,541^{* * *}$ & 0.068 \\
\hline & $(1,886)$ & $(0.003)$ & $(1,691)$ & $(0.003)$ & $(0.003)$ & $(0.003)$ & $(1,617)$ & $(0.003)$ \\
\hline \multirow[t]{2}{*}{ Cognitive skills sq. } & & & & & $0.009^{* * *}$ & & & \\
\hline & & & & & $(0.002)$ & & & \\
\hline \multirow[t]{2}{*}{ Noncognitive skills sq. } & & & & & -0.000 & & & \\
\hline & & & & & $(0.002)$ & & & \\
\hline \multirow[t]{2}{*}{ Cognitive*Noncognitive skills } & & & & & 0.018 & & & \\
\hline & & & & & $(0.003)$ & & & \\
\hline Sample & $\begin{array}{l}\text { Unrestricted } \\
\text { core sample }\end{array}$ & $\begin{array}{l}\text { Unrestricted } \\
\text { core sample }\end{array}$ & $\begin{array}{c}\text { Restricted } \\
\text { family sample }\end{array}$ & $\begin{array}{c}\text { Restricted } \\
\text { family sample }\end{array}$ & $\begin{array}{c}\text { Restricted } \\
\text { family sample }\end{array}$ & $\begin{array}{l}\text { Restricted core } \\
\text { sample }\end{array}$ & $\begin{array}{l}\text { Restricted } \\
\text { core sample }\end{array}$ & $\begin{array}{l}\text { Restricted core } \\
\text { sample, only } \\
\text { men who } \\
\text { enlisted }\end{array}$ \\
\hline Year & 2006 & 2006 & 2006 & 2006 & 2006 & $2004-2006$ & 2004-2006 & 2006 \\
\hline Observations & 15,798 & 14,807 & 24,872 & 11,983 & 9,309 & 37,294 & 43,882 & 12,651 \\
\hline R-squared & 0.153 & 0.286 & 0.138 & 0.273 & 0.293 & 0.278 & 0.171 & 0.287 \\
\hline
\end{tabular}

All regression are estimated with OLS with the small set of covariates, except for (3) and (4) which do not include control variables for family background (parental income and marriage status) and (8) which does not include enlistment status. Earnings and log wages for 2004 and 2005 have been adjusted for inflation to 2006 price levels. Robust standard errors in parenthesis. Standard errors have been clustered at the individual level in regression (6) and (7). The "restricted" sample excludes self-employed, workers in the agricultural sector and students 
Table B6: Selection into the military service

\begin{tabular}{lcc}
\hline & $(1)$ OLS & $(2)$ OLS \\
\hline Dependent variable & Enlistment & Attrition \\
\cline { 2 - 3 } Cognitive skills & -0.000 & -0.004 \\
& $(0.002)$ & $(0.004)$ \\
Noncognitive skills & $0.005^{\star \star}$ & $-0.031^{\star \star \star}$ \\
& $(0.003)$ & $(0.003)$ \\
Education: Primary school & & -0.011 \\
& & $(0.028)$ \\
Education: Secondary school & & -0.027 \\
& & $(0.026)$ \\
Education: Two years beyond secondary school & & -0.035 \\
& & $(0.027)$ \\
Education: University & & -0.012 \\
& & $(0.025)$ \\
\hline Observations & 7552 & 13133 \\
R-squared & 0.727 & 0.008 \\
\hline Aftion from
\end{tabular}

Attrition from the military service occurs when a conscripts is enlisted but does not begin the military service. Regression (1) entails the full set of health status dummies but no additional covariates. Excluded education category in (2) is a PhD. Robust standard errors in parenthesis. 
Figure B1: Histogram of age at the onset of the military service

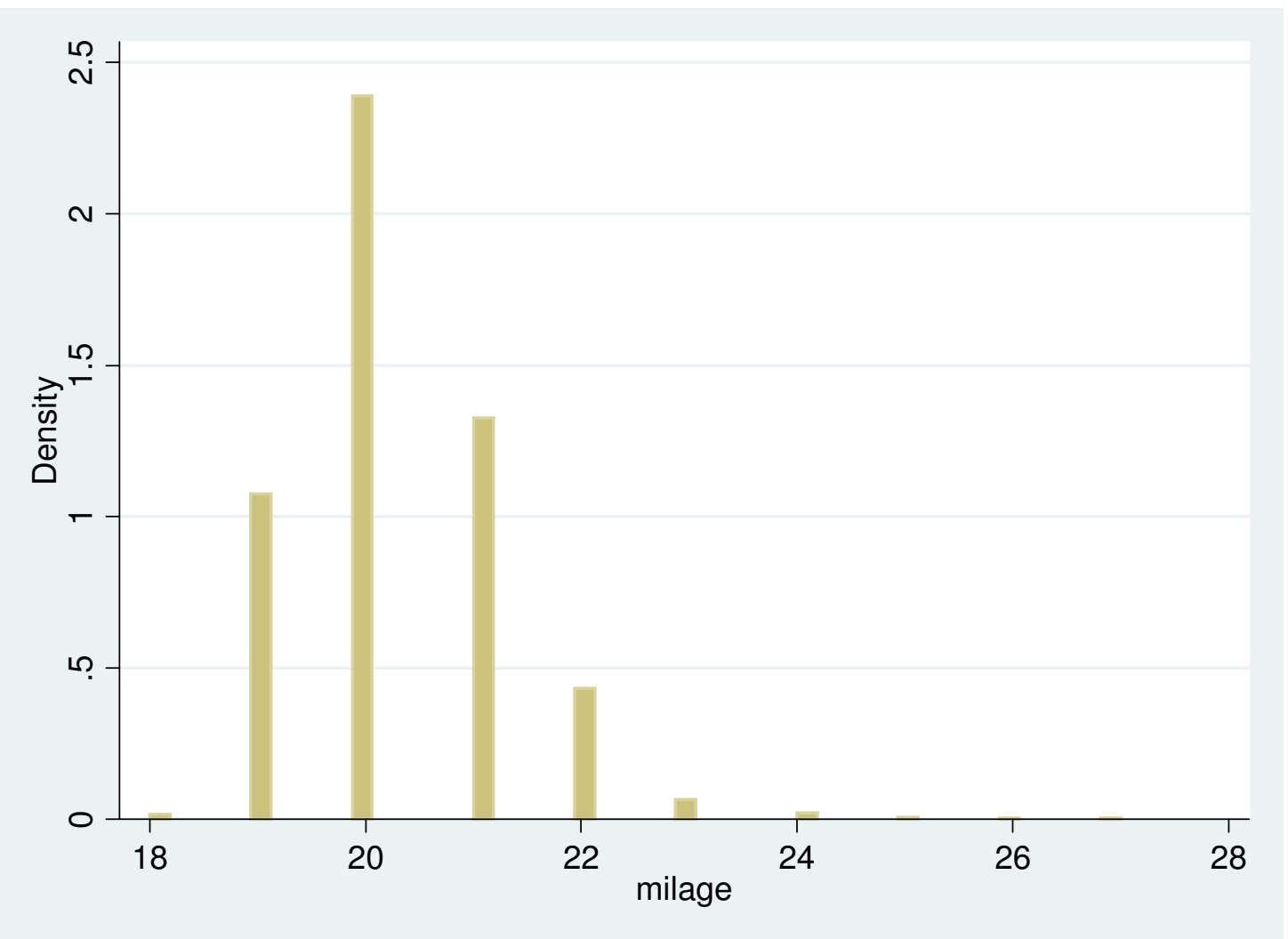

"milage" refers to age at the onset of the military service. 
Table D1: Unemployment and earnings - additional analysis

\begin{tabular}{|c|c|c|c|c|c|}
\hline & (1) OLS & (2) OLS & (3) OLS & (4) OLS & (5) OLS \\
\hline Dependent variable & $\begin{array}{l}\text { Unemployment } \\
\text { support }\end{array}$ & $\begin{array}{l}\text { Unemployment } \\
\text { support }\end{array}$ & $\begin{array}{c}\text { Annual } \\
\text { earnings } \\
\text { (SEK) }\end{array}$ & $\begin{array}{l}\text { Annual } \\
\text { earnings } \\
\text { (SEK) }\end{array}$ & $\begin{array}{l}\text { Log of annual } \\
\text { earnings }\end{array}$ \\
\hline Cognitive skills & $\begin{array}{c}-0.012^{* \star \star} \\
(0.003)\end{array}$ & $\begin{array}{c}-0.011^{* * *} \\
(0.004)\end{array}$ & $\begin{array}{c}18,121^{* * *} \\
(2,045)\end{array}$ & $\begin{array}{c}27,146^{\star * *} \\
(2,125)\end{array}$ & $\begin{array}{c}0.082^{\star * *} \\
(0.003)\end{array}$ \\
\hline Noncognitive skills & $\begin{array}{c}-0.021^{\star * *} \\
(0.003)\end{array}$ & $\begin{array}{c}-0.033^{\star * \star} \\
(0.004)\end{array}$ & $\begin{array}{c}32,730^{* * *} \\
(1,987)\end{array}$ & $\begin{array}{c}49,871^{\star * *} \\
(2,575)\end{array}$ & $\begin{array}{c}0.075^{\star * *} \\
(0.004)\end{array}$ \\
\hline Covariate set & Large & Small & Large & Small & Small \\
\hline Measurement error correction & No & Yes & No & Yes & No \\
\hline Sample restriction & No & No & No & No & $\begin{array}{c}\text { Earnings above } \\
120,000 \text { SEK }\end{array}$ \\
\hline Observations & 13732 & 14626 & 13732 & 14626 & 13229 \\
\hline R-squared & 0.042 & 0.033 & 0.198 & 0.187 & 0.213 \\
\hline
\end{tabular}


Table D2: Quantile regression, small set of covariates

\begin{tabular}{|c|c|c|c|c|c|c|c|c|c|}
\hline & 10 & 15 & 20 & 25 & 30 & 35 & 40 & 45 & 50 \\
\hline Cognitive skills & $\begin{array}{c}21,151^{* * *} \\
(5,578)\end{array}$ & $\begin{array}{c}19,090^{\star * *} \\
(2,807)\end{array}$ & $\begin{array}{c}15,446^{\star * *} \\
(1,476)\end{array}$ & $\begin{array}{c}15,628^{* \star *} \\
(1,299)\end{array}$ & $\begin{array}{c}15,452^{* \star *} \\
(1,163)\end{array}$ & $\begin{array}{c}16,228^{\star * *} \\
(1,127)\end{array}$ & $\begin{array}{c}17,062^{* * *} \\
(1,119)\end{array}$ & $\begin{array}{c}19,302^{\star * \star} \\
(1,152)\end{array}$ & $\begin{array}{c}22,169^{\text {** }} \\
(1,075)\end{array}$ \\
\hline Noncognitive skills & $\begin{array}{c}52,640^{\star * *} \\
(5,246)\end{array}$ & $\begin{array}{c}38,540^{\star * *} \\
(2,885)\end{array}$ & $\begin{array}{c}24,815^{\star \star \star} \\
(1,806) \\
\end{array}$ & $\begin{array}{c}19,839^{\star * *} \\
(1,307) \\
\end{array}$ & $\begin{array}{c}18,235^{\star \star *} \\
(1,289) \\
\end{array}$ & $\begin{array}{c}18,667^{\star \star \star} \\
(1,222) \\
\end{array}$ & $\begin{array}{c}19,830^{\star * \star} \\
(1,248)\end{array}$ & $\begin{array}{c}20,705^{\star \star *} \\
(1,195) \\
\end{array}$ & $\begin{array}{c}21,302^{* * *} \\
(1,172)\end{array}$ \\
\hline & 55 & 60 & 65 & 70 & 75 & 80 & 85 & 90 & \\
\hline Cognitive skills & $\begin{array}{c}25,026^{\star * *} \\
(1,398)\end{array}$ & $\begin{array}{c}30,406^{\star * *} \\
(1,441)\end{array}$ & $\begin{array}{c}36,184^{\star * *} \\
(1,540)\end{array}$ & $\begin{array}{c}41,297^{* * *} \\
(1,887)\end{array}$ & $\begin{array}{c}47,808^{\star * *} \\
(2,534)\end{array}$ & $\begin{array}{c}50,141^{\star * *} \\
(2,899)\end{array}$ & $\begin{array}{c}53,165^{\star \star \star} \\
(3,462)\end{array}$ & $\begin{array}{c}66,409^{* * *} \\
(5,570)\end{array}$ & \\
\hline Noncognitive skills & $\begin{array}{c}23,767^{\star * *} \\
(1,350)\end{array}$ & $\begin{array}{c}26,324^{\star * *} \\
(1,315)\end{array}$ & $\begin{array}{c}28,257^{\star * *} \\
(1,610)\end{array}$ & $\begin{array}{c}31,073^{\star * *} \\
(1,650)\end{array}$ & $\begin{array}{c}33,288^{\star * *} \\
(2,073)\end{array}$ & $\begin{array}{c}39,494^{\star * *} \\
(2,552)\end{array}$ & $\begin{array}{c}47,307^{\star * \star} \\
(2,849)\end{array}$ & $\begin{array}{c}59,705^{\star * *} \\
(5,172)\end{array}$ & \\
\hline
\end{tabular}

Unconditional quantiles estimated using [rifreg] command by Firpo, Fortin and Lemieux (2009) with a Gaussian kernel function and the optimal bandwith according to Silverman (1986) (14,155.918). All regressions include the "small" set of covariates as defined in Table 1. Standard errors estimated by bootstrap (50 replications). Sample size is 14,626 observations.

Table D3: Quantile regression, large set of covariates

\begin{tabular}{|c|c|c|c|c|c|c|c|c|c|}
\hline & 10 & 15 & 20 & 25 & 30 & 35 & 40 & 45 & 50 \\
\hline Cognitive skills & $\begin{array}{c}13,025^{\text {** }} \\
(4,965)\end{array}$ & $\begin{array}{c}13,673^{* * *} \\
(2,696)\end{array}$ & $\begin{array}{c}11,296^{\star * *} \\
(1,958)\end{array}$ & $\begin{array}{c}12,168^{* * *} \\
(1,583)\end{array}$ & $\begin{array}{c}11,130^{* * *} \\
(1,343)\end{array}$ & $\begin{array}{c}1,306^{\star * *} \\
(1,193)\end{array}$ & $\begin{array}{c}1,658^{\star * *} \\
(1,199)\end{array}$ & $\begin{array}{c}13,080^{\text {** }} \\
(1,029)\end{array}$ & $\begin{array}{c}14,193^{\star * *} \\
(1,016)\end{array}$ \\
\hline Noncognitive skills & $\begin{array}{c}47,224^{\star * *} \\
(5,420)\end{array}$ & $\begin{array}{c}34,762^{\star * *} \\
(3,259) \\
\end{array}$ & $\begin{array}{c}23,000 \text { *** } \\
(1,837) \\
\end{array}$ & $\begin{array}{c}18,527^{\star * *} \\
(1,303) \\
\end{array}$ & $\begin{array}{c}16,660^{\star \star *} \\
(1,165) \\
\end{array}$ & $\begin{array}{c}17,185^{\star * *} \\
(1,230) \\
\end{array}$ & $\begin{array}{c}17,975^{\star \star *} \\
(911) \\
\end{array}$ & $\begin{array}{c}18,704^{\star * *} \\
(1,098)\end{array}$ & $\begin{array}{l}19,165^{\star * *} \\
(1,233)\end{array}$ \\
\hline & 55 & 60 & 65 & 70 & 75 & 80 & 85 & 90 & \\
\hline Cognitive skills & $\begin{array}{c}15,364^{\text {** }} \\
(1,228)\end{array}$ & $\begin{array}{c}18,809^{* * *} \\
(1,424)\end{array}$ & $\begin{array}{c}21,640^{* * *} \\
(1,555)\end{array}$ & $\begin{array}{c}24,005^{\star \star *} \\
(1,828)\end{array}$ & $\begin{array}{c}26,866^{\star \star *} \\
(2,067)\end{array}$ & $\begin{array}{c}25,310^{\star \star *} \\
(2,120)\end{array}$ & $\begin{array}{c}26,522^{\star \star *} \\
(3,539)\end{array}$ & $\begin{array}{c}35,205^{\star \star *} \\
(5,070)\end{array}$ & \\
\hline
\end{tabular}

Unconditional quantiles estimated using [rifreg] command by Firpo, Fortin and Lemieux (2009) with a Gaussian kernel function and the optimal bandwith according to Silverman (1986) (14,369.705). All regressions include the "small" set of covariates as defined in Table 1. Standard errors estimated by bootstrap (50 replications). Sample size is 13,732 observations. 
Table D4: Robustness for omitted variables (log wages)

\begin{tabular}{|c|c|c|c|c|}
\hline & (1) & (2) & (3) & (4) \\
\hline \multirow[t]{2}{*}{ Cognitive skills } & $0.075^{\star \star \star}$ & $0.079^{\star \star \star}$ & $0.079^{* \star *}$ & $0.085^{\star \star \star}$ \\
\hline & $(0.003)$ & $(0.003)$ & $(0.003)$ & $(0.003)$ \\
\hline \multirow[t]{2}{*}{ Noncognitive skills } & $0.052^{\star \star \star}$ & $0.059^{\star * *}$ & $0.059^{\star \star \star}$ & $0.067^{\star \star \star}$ \\
\hline & $(0.003)$ & $(0.003)$ & $(0.004)$ & $(0.003)$ \\
\hline Sample restrictions & & $\begin{array}{c}\text { Health status } \\
\text { observed }\end{array}$ & $\begin{array}{l}\text { Health } \\
\text { status } \\
\text { observed }\end{array}$ & \\
\hline Additional controls & $\begin{array}{l}\text { Type of military } \\
\text { service }\end{array}$ & - & $\begin{array}{l}\text { Health } \\
\text { status }\end{array}$ & $\begin{array}{c}\text { Age at } \\
\text { draft }\end{array}$ \\
\hline Observations & 13974 & 7198 & 7198 & 13845 \\
\hline R-squared & 0.301 & 0.283 & 0.285 & 0.294 \\
\hline
\end{tabular}

Dependent variable is the log of wage measure W2. All regressions include the

"small" set of covariates as defined in Table 1 and are estimated using OLS. Heteroskedasticity-robust standard errors in parenthesis. 
Table E1: Occupational choice, marginal effects from multinomial logit

\begin{tabular}{|c|c|c|c|c|c|c|}
\hline & \multicolumn{2}{|c|}{ Managers } & \multicolumn{2}{|c|}{ Skilled } & \multicolumn{2}{|c|}{ Unskilled } \\
\hline Cognitive skills & $\begin{array}{c}0.027^{\star * *} \\
(0.003)\end{array}$ & $\begin{array}{c}0.021^{\star \star *} \\
(0.004)\end{array}$ & $\begin{array}{c}0.173^{* * *} \\
(0.007)\end{array}$ & $\begin{array}{c}0.120^{\star * *} \\
(0.008)\end{array}$ & $\begin{array}{c}-0.200^{* * *} \\
(0.007)\end{array}$ & $\begin{array}{c}-0.141^{\star * *} \\
(0.008)\end{array}$ \\
\hline Noncognitive skills & $\begin{array}{c}0.044^{\star * *} \\
(0.003)\end{array}$ & $\begin{array}{c}0.045^{\star \star *} \\
(0.003)\end{array}$ & $\begin{array}{c}0.087^{\star * *} \\
(0.006)\end{array}$ & $\begin{array}{c}0.070^{\star * *} \\
(0.007)\end{array}$ & $\begin{array}{c}-0.131^{* * *} \\
(0.007)\end{array}$ & $\begin{array}{c}-0.116^{\star * *} \\
(0.007)\end{array}$ \\
\hline Covariate set & Small & Large & Small & Large & Small & Large \\
\hline Observations & 12,274 & 11,575 & 12,274 & 11,575 & 12,274 & 11,575 \\
\hline
\end{tabular}

Standard errors in parentheses. We exclude men who work in the military. See Table 1 for more

information.

Table E2: Occupation specific skill prices

\begin{tabular}{|c|c|c|c|c|c|c|}
\hline & \multicolumn{2}{|c|}{ Managers } & \multicolumn{2}{|c|}{ Skilled occupations } & \multicolumn{2}{|c|}{$\begin{array}{c}\text { Unskilled } \\
\text { occupations }\end{array}$} \\
\hline & (1) Lee & (2) BFG & (3) Lee & (4) BFG & (5) Lee & BFG \\
\hline \multirow[t]{2}{*}{ Cognitive skills } & $0.058^{* *}$ & $0.067^{\star \star}$ & $0.081^{\star \star *}$ & $0.082^{* \star *}$ & $0.022^{\star \star}$ & $0.034^{*}$ \\
\hline & $(0.023)$ & $(0.029)$ & $(0.009)$ & $(0.011)$ & $(0.009)$ & $(0.017)$ \\
\hline \multirow[t]{2}{*}{ Noncognitive skills } & $0.107^{\star \star \star}$ & $0.092^{*}$ & $0.061^{\star \star *}$ & $0.056^{* * *}$ & $0.038^{* \star *}$ & $0.044^{\star \star \star}$ \\
\hline & $(0.029)$ & $(0.054)$ & $(0.007)$ & $(0.015)$ & $(0.006)$ & $(0.010)$ \\
\hline Observations & 611 & 609 & 3036 & 2993 & 2975 & 2975 \\
\hline R-squared & 0.362 & 0.366 & 0.288 & 0.283 & 0.069 & 0.073 \\
\hline
\end{tabular}

Dependent variable is log wages (W2) in all regressions. All regressions include the large set of covariates as defined in Table 1. Standard errors calculated with bootstrap (50 repetitions). Specification (1), (3) and (5) use the selection correction method in Lee (1983) while (2), (4) and (6) use Bourguignon et al. (2007). All specifications are estimated using the [selmlog] STATA software developed by use Bourguignon et al. (2007). 
Table E2, cont: Selection stage

\begin{tabular}{|c|c|c|c|}
\hline \multirow[t]{9}{*}{ No observation on occupation } & Cognitive skill & -0.265 & 0.049 \\
\hline & Noncognitive skill & -0.306 & 0.044 \\
\hline & Region 1980: Gothenburg & 0.368 & 0.214 \\
\hline & Region 1980: Stockholm & 0.243 & 0.163 \\
\hline & Region 1980: Malmö & 0.695 & 0.236 \\
\hline & Region 1980: South & -0.087 & 0.162 \\
\hline & Region 1980: Middle & -0.383 & 0.198 \\
\hline & Mother white-collar 1980 & -0.190 & 0.084 \\
\hline & Father white-collar 1980 & -0.074 & 0.084 \\
\hline \multirow[t]{9}{*}{ Managers } & Cognitive skill & -0.012 & 0.061 \\
\hline & Noncognitive skill & 0.344 & 0.054 \\
\hline & Region 1980: Gothenburg & -0.348 & 0.274 \\
\hline & Region 1980: Stockholm & 0.192 & 0.186 \\
\hline & Region 1980: Malmö & 0.166 & 0.283 \\
\hline & Region 1980: South & 0.486 & 0.181 \\
\hline & Region 1980: Middle & -0.084 & 0.219 \\
\hline & Mother white-collar 1980 & -0.220 & 0.102 \\
\hline & Father white-collar 1980 & -0.206 & 0.100 \\
\hline \multirow[t]{9}{*}{ Unqualified workers } & Cognitive skill & -0.466 & 0.042 \\
\hline & Noncognitive skill & -0.343 & 0.039 \\
\hline & Region 1980: Gothenburg & 0.302 & 0.203 \\
\hline & Region 1980: Stockholm & 0.012 & 0.152 \\
\hline & Region 1980: Malmö & 0.200 & 0.231 \\
\hline & Region 1980: South & -0.186 & 0.149 \\
\hline & Region 1980: Middle & -0.477 & 0.175 \\
\hline & Mother white-collar 1980 & -0.167 & 0.071 \\
\hline & Father white-collar 1980 & -0.107 & 0.073 \\
\hline
\end{tabular}

excluded from the Table due to space considerations. 
Table F1: Log wages - skill measures based on the sum of subscores

\begin{tabular}{|c|c|c|c|c|c|c|}
\hline & (1) & $(2)$ & (3) & $(4)$ & (5) & (6) \\
\hline \multirow[t]{2}{*}{ Cognitive skills } & $0.084^{* * *}$ & $0.048^{* * *}$ & $0.090^{* * *}$ & $0.104^{* * *}$ & & $0.085^{* * *}$ \\
\hline & $(0.003)$ & $(0.003)$ & $(0.004)$ & $(0.003)$ & & $(0.003)$ \\
\hline \multirow[t]{2}{*}{ Noncognitive skills } & $0.065^{\star * *}$ & $0.057^{* * *}$ & $0.098^{* * *}$ & & $0.090^{\star \star *}$ & $0.066^{\star \star *}$ \\
\hline & $(0.003)$ & $(0.003)$ & $(0.005)$ & & $(0.003)$ & $(0.003)$ \\
\hline \multirow[t]{2}{*}{ Cognitive skills sq. } & & & & & & $0.009^{* \star *}$ \\
\hline & & & & & & $(0.002)$ \\
\hline \multirow[t]{2}{*}{ Noncognitive skills sq. } & & & & & & -0.001 \\
\hline & & & & & & $(0.002)$ \\
\hline \multirow[t]{2}{*}{ Noncognitive ${ }^{\star}$ Cognitive } & & & & & & $0.014^{* * *}$ \\
\hline & & & & & & $(0.003)$ \\
\hline Covariate set & Small & Large & Small & Small & Small & Small \\
\hline Measurement error correction & No & No & Yes & No & No & No \\
\hline Observations & 10761 & 10090 & 10761 & 12542 & 11396 & 10761 \\
\hline R-squared & 0.290 & 0.342 & 0.318 & 0.262 & 0.235 & 0.295 \\
\hline
\end{tabular}

This table replicates Table 1 except for the measure of cognitive and noncognitive which are based on the sum of subscores. 
Table F2: Pairwise correlations between cognitive subscores

\begin{tabular}{|c|c|c|c|c|}
\hline & Logic ability & Verbal ability & $\begin{array}{l}\text { Technological } \\
\text { comprehension }\end{array}$ & Metal rotation \\
\hline Logic ability & 1.0000 & & & \\
\hline Verbal ability & 0.6840 & 1.0000 & & \\
\hline Technological comprehension & 0.5445 & 0.5023 & 1.0000 & \\
\hline Metal folding & 0.6062 & 0.5206 & 0.5753 & 1.0000 \\
\hline
\end{tabular}

Table F3: Log wages - Cognitive subscores

\begin{tabular}{|c|c|c|c|c|c|}
\hline & $(1)$ & (2) & (3) & $(4)$ & $(5)$ \\
\hline \multirow[t]{2}{*}{ Logic ability } & $0.041^{* * *}$ & & & & $0.023^{\star \star \star}$ \\
\hline & $(0.001)$ & & & & $(0.002)$ \\
\hline \multirow[t]{2}{*}{ Verbal ability } & & $0.040^{* * *}$ & & & $0.011^{* \star *}$ \\
\hline & & $(0.001)$ & & & $(0.002)$ \\
\hline \multirow[t]{2}{*}{ Technological comprehension } & & & $0.042^{\star \star \star}$ & & $0.022^{\star \star \star}$ \\
\hline & & & $(0.001)$ & & $(0.002)$ \\
\hline \multirow[t]{2}{*}{ Metal folding } & & & & $0.033^{\star * *}$ & $0.004^{* *}$ \\
\hline & & & & $(0.001)$ & $(0.002)$ \\
\hline Observations & 12967 & 12967 & 12967 & 12967 & 12967 \\
\hline R-squared & 0.236 & 0.218 & 0.227 & 0.211 & 0.254 \\
\hline
\end{tabular}

Dependent variable is the log wages (W2). Each ability measure is set on a 1-9 scale (the measures are

not normalized). All regressions are estimated with OLS and include the small set of covariates. See

Table 1 for more information. 
Table F4: Pairwise correlations between noncognitive subscores

\begin{tabular}{lllll}
\hline & Score 1 & Score 2 & Score 3 & Score 4 \\
Score 1 & 1.0000 & & & \\
Score 2 & 0.4588 & 1.0000 & & \\
Score 3 & 0.6219 & 0.5319 & 1.0000 & \\
Score 4 & 0.6270 & 0.4672 & 0.5661 & 1.0000 \\
\hline
\end{tabular}

Table F5: Log wages - Noncognitive subscores

\begin{tabular}{|c|c|c|c|c|c|}
\hline & (1) & (2) & (3) & (4) & $(5)$ \\
\hline \multirow[t]{2}{*}{ Score 1} & $0.106^{\star * *}$ & & & & $0.056^{\star * *}$ \\
\hline & $(0.004)$ & & & & $(0.005)$ \\
\hline \multirow[t]{2}{*}{ Score 2} & & $0.061^{* * *}$ & & & $0.016^{\star * *}$ \\
\hline & & $(0.003)$ & & & $(0.004)$ \\
\hline \multirow[t]{2}{*}{ Score 3} & & & $0.105^{\star \star \star}$ & & $0.044^{* * *}$ \\
\hline & & & $(0.004)$ & & $(0.005)$ \\
\hline \multirow[t]{2}{*}{ Score 4} & & & & $0.103^{* * *}$ & 0.037 \\
\hline & & & & $(0.004)$ & $(0.006)$ \\
\hline Observations & 11445 & 11432 & 11441 & 11432 & 11396 \\
\hline R-squared & 0.221 & 0.195 & 0.215 & 0.210 & 0.237 \\
\hline
\end{tabular}

Dependent variable is log wages (W2). Each ability measure is set on a 1-5 scale (the measures are not

normalized). All regressions are estimated with OLS and include the small set of covariates. See Table 1

for more information. 
Table F6: Log wages - residualized measures

\begin{tabular}{|c|c|c|}
\hline & (1) & (2) \\
\hline Cognitive skills & $\begin{array}{c}0.111^{\star \star \star} \\
(0.002)\end{array}$ & \\
\hline Noncognitive skills & & $\begin{array}{c}0.100^{* * *} \\
(0.003)\end{array}$ \\
\hline Cognitive skills - residualized & & $\begin{array}{c}0.086^{\star \star *} \\
(0.003)\end{array}$ \\
\hline Noncognitive skills - residualized & $\begin{array}{c}0.066^{\star \star *} \\
(0.003)\end{array}$ & \\
\hline Observations & 13974 & 13974 \\
\hline R-squared & 0.294 & 0.294 \\
\hline
\end{tabular}

\section{Table F7: Effect of cognitive ability score on measured noncognitive ability score}

\begin{tabular}{ll}
\hline Final cognitive ability score (1-9) & $\begin{array}{l}0.109^{\star * *} \\
(0.008)\end{array}$ \\
\hline Observations & 494,981 \\
R-squared & 0.170 \\
\hline Dependent variable is noncognitive ability $(1-9)$. The \\
regression includes a fifth order polynomial of the sum of \\
cognitive ability subscores interacted with draft year.
\end{tabular}

